\title{
Norois
}

Environnement, aménagement, société

$247 \mid 2018$

Recherche touristique : perspectives latinoaméricaines

\section{Dispossession, displacement and subordination in the construction of tourist areas: Central America as a conflict scenario}

Desposesión, desplazamiento y subordinación en la construcción del espacio turístico: Centroamérica como escenario de conflicto

Dépossession, déplacement et subordination dans la construction d'un espace touristique : l'Amérique centrale comme enjeu de conflit

\section{Ernest Cañada}

\section{(2) OpenEdition}

\section{Journals}

Electronic version

URL: https://journals.openedition.org/norois/6568

DOI: 10.4000/norois.6568

ISBN: 978-2-7535-7629-2

ISSN: 1760-8546

\section{Publisher}

Presses universitaires de Rennes

\section{Printed version}

Date of publication: 19 September 2018

Number of pages: 49-62

ISBN: 978-2-7535-7570-7

ISSN: 0029-182X

Electronic reference

Ernest Cañada, "Dispossession, displacement and subordination in the construction of tourist areas: Central America as a conflict scenario", Norois [Online], 247 | 2018, Online since 19 September 2020, connection on 13 January 2022. URL: http://journals.openedition.org/norois/6568 ; DOI: https:// doi.org/10.4000/norois.6568 


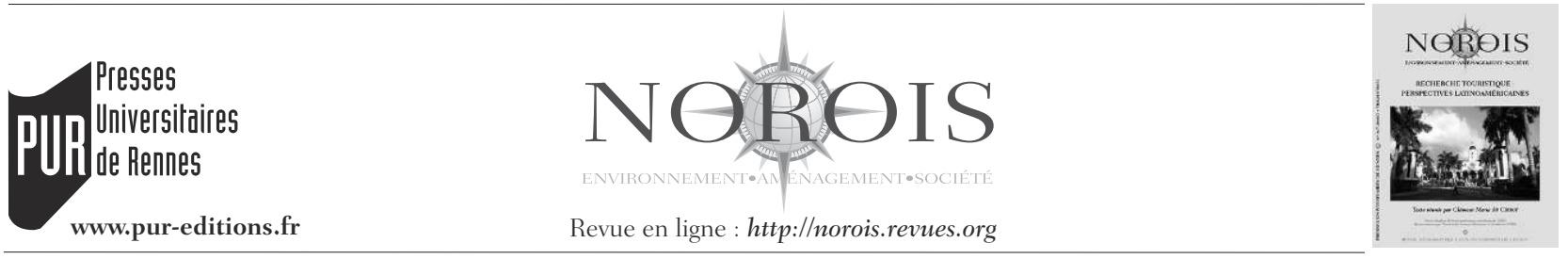

\title{
Dispossession, Displacement and Subordination in the Construction of Tourist Areas: Central America as a Conflict Scenario
}

\author{
Dépossession, déplacement et subordination dans la construction d'un espace touristique : \\ l'Amérique centrale comme enjeu de conflit \\ Desposesión, desplazamiento y subordinación en la construcción del espacio turístico: \\ Centroamérica como escenario de conflicto
}

\author{
Ernest CAÑADA
}

Alba Sud/Grupo de Investigación en Sostenibilidad y Territorio de la Universidad de las Islas Baleares (GIST / UIB)-C/ Bilbao 31, 4º 1 , esc. A, 08005 Barcelona, España. (ernest@albasud.org)

\begin{abstract}
The creation of new tourist areas forms part of the spatiotemporal capital fixes available to territories to deal with the different crises that affect them. The transformation of these territories into functional areas for a new logic of accumulation has a profound impact on their different population groups and on nature. As a consequence of the major drive in tourism from the late 1990s to the early 2000s, Central America has become the ideal setting to observe and analyze how this metamorphosis occurs. In this sense, based on the analysis of the conflicts that have arisen, three major dynamics for these new tourist areas have been identified: (a) the dispossession of natural resources and the dismantling of preexisting territory; (b) intensive population movements that expel and attract different groups; and (c) subordinate integration of those from rural communities into new tourism activities that are central to the economy in these areas. This transformation exhibits a structurally violent nature. Using this interpretation framework, this article proffers approaches on how to move forward with a research agenda that enables a deeper understanding of the construction processes underpinning tourist areas, based on the Central American case study.
\end{abstract}

Résumé : La création de nouveaux espaces touristiques fait partie des solutions spatio-temporelles développées en réponse aux crises structurelles du capitalisme. La transformation de ces territoires en espaces fonctionnels liées aux nouvelles logiques d'accumulation a un impact profond sur les différents groupes de population et sur la nature. Le cas de l'Amérique centrale, caractérisé par une forte croissance de l'activité touristique entre la fin des années 1990 et le début des années 2000, constitue un terrain d'étude privilégié pour l'observation et l'analyse de ces recompositions. À partir de l'analyse des conflits générés, trois dynamiques majeures peuvent être identifiées: a) la dépossession des ressources naturelles et le démantèlement des formes d'organisation territoriale préexistantes; b) des phénomènes d'expulsion ou, au contraire, d'attraction de nouvelles populations; c) La subordination de la population issue des communautés rurales aux nouvelles activités touristiques devenues centrales dans l'économie de ces territoires. La transformation et la création de nouveaux territoires touristiques acquièrent ainsi une nature structurellement violente. À partir de ce cadre d'interprétation et sur la base d'une étude de cas centraméricaine, cet article propose une approche permettant de mieux comprendre les processus que sous-tendent la production de l'espace touristique.

Resumen: La creación de nuevos espacios turísticos forma parte de las soluciones espacio-temporales del capital para hacer frente a sus crisis. La transformación de estos territorios para que puedan ser funcionales a las lógicas de acumulación tiene implicaciones profundas 
en los diferentes grupos de población presentes y en la naturaleza. El caso centroamericano, con un fuerte despegue de la actividad turística entre finales de los años 90 y principios de los dos mil, constituye un escenario privilegiado para la observación y análisis de cómo se produce esta metamorfosis. Así, a partir del análisis de los conflictos generados se identifican tres grandes dinámicas: a) desposesión de recursos naturales y desarticulación territorial pre-existente; b) nuevas dinámicas de expulsión y atracción de población; c) integración subordinada de la población procedente de comunidades rurales en las nuevas actividades turísticas centrales en la economía de estos territorios. La transformación y creación de nuevos territorios turísticos adquiera una naturaleza de carácter estructuralmente violenta. A partir de este marco de interpretación se propone cómo avanzar en una agenda de investigación.

Keywords: conflict, Costa-Rica - dispossession - Guanacaste - coastline - tourism

Mots clés : conflit - Costa Rica - dépossession - Guanacaste - littoral - tourisme

Palabras clave: conflictividad - Costa Rica - desposesión - Guanacaste - litoral - turismo

\section{INTRODUCTION}

Capitalism has historically shown a need for constant territorial expansion (Harvey, 2003; Luxemburg, 1912; Wallerstein, 1979). The transfer of capital to new spaces where its reproduction can be ensured is one of the responses available to deal with crises, which the geographer David Harvey terms spatiotemporal fixes (Harvey, 2013 and 2014). Each accumulation cycle develops its own territoriality, meaning the functional economic activities in a given cycle are the backbone of, and are articulated by, the specifics of said cycle, creating "made-tomeasure geographies” (Rodríguez and López, 2011).

The recurrent over-accumulation of capital may lead to devaluation when there is a recession or deflationary depression, thus necessitating "flow" and finding spaces where capital can "settle" (capital fixes) and, therefore, spatially transfer surplus capital. These "spatial fixes" have been observed in different phenomena such as colonialism, imperialism, the free movement of capital, and the geopolitical conquest of natural resources. One of the ways in which capital manages to absorb surplus capital, appreciate, and thus temporarily offset crises of capitalism is through constructed environments: the extension of cities, the creation of large infrastructure that enables surpluses to be directed into new investment opportunities, such as airports, roads, or ports for cruise ships, that are intimately linked with the development of tourism (Blàzquez, 2013), or into new types of diffuse urban planning in rural coastal areas linked to residential tourism.

The result of this dynamic, whereby capital seeks better conditions for its reproduction, gives rise to permanently unstable landscapes built on the basis of natural elements with relative permanence. Capital therefore has to devalue a large part of the fixed capital invested in a constructed environment under a specific logic of accumulation to be able to move on to a new cycle of accumulation. This leads to intensive and destructive localized crises and the configuration of new landscapes molded around a series of natural determining factors that grant that territory a specific role in the new dominant form of accumulation. This displacement involves reconfiguring territories based on the new dynamics of accumulation and represents the implementation of transformation processes in these spaces and in the different social groups they house, as well as in their territorial organization. They are part of a global dynamic of spatial re-functionalization based on the logic of accumulation, which Peter Rosset terms a "war for land and territory" (2009).

The construction of territories that are suitable for accumulation based on tourism activities, deemed one of the "solutions" of capitalism (Fletcher, 2011 ), requires certain logics of specialization. Critical Marxist studies have widely documented this role of tourism as an accumulation strategy (Fletcher, 2016). In order to ensure the dynamics of large-scale capital reproduction, these spaces need to focalize many offers and infrastructures to make them appealing, to generate economies of scale encompassing many complementary activities, and to be able to function at business levels that offer a certain scope-what is termed uneven geographic development (Smith, 2015). This involves reorganizing and repurposing territories based on the needs of accumulation for tourism as an overriding 
economic activity. In this sense, it represents the reduction in importance, displacement, and marginalization of certain economic activities and actors that previously played a fundamental role in these spaces.

This expansion of tourism gives rise to what Louis Turner and John Ash termed the "pleasure peripheries" in 1975 (Turner and Ash, 1991). Advances in aviation and airport infrastructures after World War II enabled holiday destinations around the world to expand, in such a way that these new areas were able to intermingle much more with different places around the globe and enter into greater competition with one another. A new mass holiday model was built on this expansion, accompanied by ever greater numbers of hotels, travel agencies, cruise lines and new financial mechanisms. As Turner and Ash pointed out, this new context of opportunity enabled tourism capital to choose where it located based on the comparative advantages offered by different territories in the form of "incentives" (labor costs, taxation, infrastructure, energy supplies, safety, etc.). The incorporation of new "tourist peripheries" multiplied from the 1980s onward with the drop in oil prices, which enabled major mobility expansion. More recently, the growth of financial capital has generated dynamics of accumulation that require material locations; a marvelous opportunity was offered by these new tourism areas (Murray, 2012).

The territories incorporated into the global operational logic of the tourism industry join this sector with a subordinate status, having scant ability to control the different scales through which the industry operates, as Stephen G. Britton explained in what is now seen as a key article in critical tourism studies (Britton, 1982). Consequently, global capital, in partnership with local and regional capital, directs the creation process for new tourism areas.

The penetration of tourist and real-estate capital, aided by specific national and international laws and public policies, as well as neoliberalist institutional fixes that serve its interests, leads to a radical metamorphosis in the logic of territorial structuring based on the needs of reproduction, just as earlier dominant economic structures organized territories according to their own requirements. In these new tourism spaces, nature is transformed into a commodity through the tourism/residential property busi- ness and becomes a key factor in increasing profits (Aguilar et al., 2015). In this sense, nature falls under a dynamic of plunder and reappropriation so as to render it functional for the interests of capitalist accumulation through the tourism/residential property industry (Vilchis et al., 2016), giving rise to a process of reconfiguration of the touristic landscape (Cruz-Coria et al., 2012). In turn, this dynamic forms part of the different parallel "neoliberalization" processes of nature set out by Noel Castree (2008). The expansive logic of touristic transformation, as well as the neoliberal reforms that have facilitated it, has been boosted by tourism's ability to commodify nature and culture as consumer goods (Devine, 2017).

The recent development of tourism in Central America during the 1990s and early 2000s, which has restructured its dependency on spaces that are central to global capitalism (Cordero, 2006), represents an ideal setting to observe and analyze the spatial transformations that have taken place, especially in coastal areas, owing to the hegemonic presence of the tourism/residential property industry.

The first aim of this article is to analyze how the transformation of coastal and rural territories occurs and the implications this has for the actors there, as well as for the natural environment, based on the case study of Central America. In line with this analysis, and with a basis in Marxist analysis and critical tourism studies, the second aim is to produce and propose an interpretation framework for the processes of dispossession, displacement and subordination of farmers and the working class that occur as part of the construction of tourism areas. This should enable us to design a research agenda for specific case studies that can attest to the historic transformation process observed in Central America and, in turn, provide further depth and complexity to this analysis.

Our methodology is based on a literature review of studies regarding tourism development in Central America and on a specific analysis of tourism conflicts, understood as key to visualizing the deeper dynamics of social change. More specifically, these are redistribution conflicts between economic sectors competing for insufficient resources and between different social groups-those who successfully join the new sector and those who are marginalized and excluded from enjoying its bene- 
fits or who retain a subordinate status (Cañada and Gascón, 2016; Gascón, 2012). In order to understand these tourism conflicts, we require a theoretical and methodological framework based on political ecology and classical Marxist political economy. This conflict analysis is performed on the basis of academic analyses, where they exist, and on information in the media and documentation issued by actors themselves. The article is organized into two broad sections. The first sets out the growing importance of tourism in Central America. The three main processes that have led to the construction of tourism areas in coastal territories are then identified from the perspective of rural inhabitants: dispossession from natural resources and the dismantling of preexisting territory; the new migration dynamics of expulsion and attraction; and, finally, the subordinate integration of inhabitants from rural communities into the new tourism activities that are central to the economy in these areas. The article concludes with some considerations by way of conclusions regarding the nature of these processes and their implications within political economy and ecology, as well as a series of considerations that rethink the research agenda concerning tourism in Central America.

\section{Central America as a New Tourism Periphery}

Over the last two decades, tourism has taken on an ever greater presence in the Central American region. In 2002, Central America welcomed 4.5 mil-

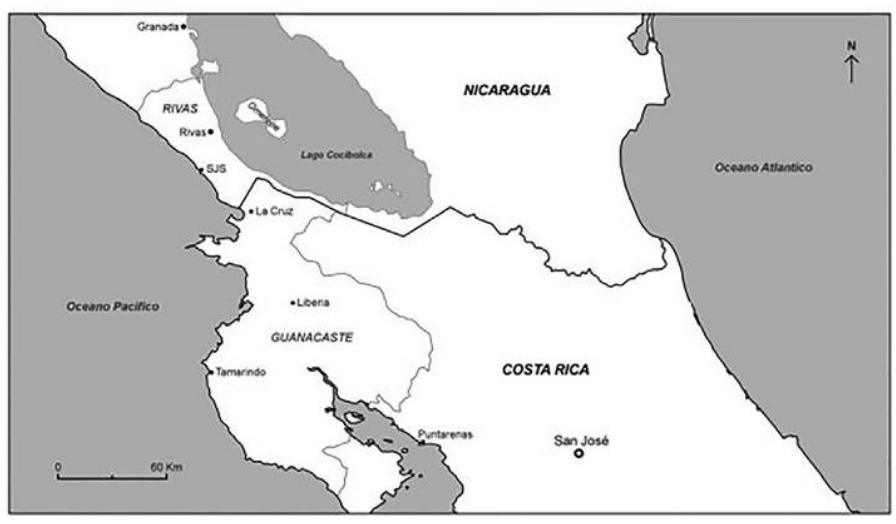

Figure 1: A location map of the main tourist areas in Costa Rica and Nicaragua (Source: prepared by the author) Nicaragua

Localisation des principales zones touristiques au Costa Rica et au

Ubicación de las principales zonas turísticas en Costa Rica y Nicaragua lion tourists; by 2016, this figure had surpassed the 10-million mark, according to available statistical reports (SITCA, 2013, 2016). In turn, economic income from tourism in 2002 stood at $\$ 3.2$ billion and reached $\$ 12.5$ billion in 2016, with increases seen across all countries. Tourism's contribution to GDP in the region stood at 5.2\% in 2016 (SITCA, 2016).

However, the role of tourism in the structural transformation of the region's integration into the international economy between the end of the 1970 s and the first decade of the 2000s is more important still. In 1978 , over $70 \%$ of foreignexchange income in the region came from traditional agricultural exports of cotton, bananas, sugar, coffee and meat, whereas 30 years later, and with a more complex model of integration into the global economy, foreign-exchange income came predominantly from remittances, exports of traditional and nontraditional agricultural produce, toll manufacturing, and tourism. At this time, the weight of foreign-exchange income from traditional agricultural exports fell sharply across all countries, to rates ranging from 4\% in El Salvador to 18\% in Nicaragua. In turn, the main source of foreign exchange in Guatemala, El Salvador, Honduras and Nicaragua was remittances sent by migrant populations, ranging from 34\% in Nicaragua to 55\% in El Salvador. Furthermore, tourism took on a greater role in all countries: 23\% in Costa Rica; 17\% in Nicaragua; $15 \%$ in Honduras; $13 \%$ in El Salvador, and $12 \%$ in Guatemala (Rosa, 2008).

The growing importance of tourism in Central America is not uniform across the region, but instead concentrated in certain zones with potential appeal, especially coastal areas, colonial cities and specific natural settings, with the territorial transformation this entails.

The factor that drives this type of change dynamic is the penetration of domestic and foreign tourism and real-estate capital (or partnerships in many instances) bolstered on the one hand by a series of policies and institutional structures that frequently provide protection, resources and support through different mechanisms and instruments, and, on the other, by the history of globalization in the tourism industry (Fernández and Ruiz, 2010). This means, for example, that all countries in Central America signed up to the International Centre for Settlement 
of Investment Disputes (ICSID), headquartered in Washington, DC, and associated with the World Bank, which is the main guarantor of international capital with regard to possible disputes in the country where the investment is made; or the passing of laws that are favorable to foreign investment and the creation of investment promotion agencies - both with a prominent role in tourism (CEPAL, 2001; Cuéllar, 2012).

Along the same lines, from the late 1980s to the early 1990s, most countries in the region implemented structural adjustment policies and opened up to international markets. These movements were undertaken as the countries in question required foreign currencies to service foreign debt under the influence of multilateral organizations such as the World Bank and the International Monetary Fund, as occurred in other impoverished nations during the same period (Dieke, 1995; Hawkins and Mann, 2006; Konadu-Agyemang, 2001). This new framework for tourism took on a privileged role, as has been widely documented in the case of Costa Rica, where a set of policies were implemented that clearly favored the tourism sector at the expense of other industries (Arias and Muñoz, 2007; Bustos, 2010; Carvajal, 1993; Morales, 2010).

The explicit recognition of the strategic role of tourism was evidenced with the Montelimar Declaration, signed at the $18^{\text {th }}$ Meeting of Presidents of Central America at the Hotel Barceló-Montelimar in Nicaragua on May 9, 1996, whereby a commitment was made to "regional tourism integration that enables our resources, wishes and efforts to come together to project an image to the world showcasing the advantages of a unique regional tourist destination". In this sense, the agreement drove intraregional promotion, package-holiday marketing, the creation of legislation, policies and incentives for foreign investment, and private-sector cooperation (Gómez, 2008). The overwhelming argument underscoring these policies is that tourism represents an opportunity to reduce poverty and improve wellbeing among the entire population. The following statement by the Salvadorian minister of tourism, José Napoleón Duarte Durán, from 2011, is a clear example of this:

"One of the most important goals of tourism is precisely that of improving the well-being of poor communities. The conservation of their surrounding environment benefits tourism, but it also benefits communities and gives people important opportunities to transform their local economies."

(Duarte, 2011)

The different programs and plans for tourism development promoted by individual countries through their respective governments and/or in collaboration with international cooperation agencies operate on a much more detailed level—as in the case, for example, of the heritage restoration programs in colonial cities led by the Spanish Agency for International Development (AECID) or the town-planning programs in coastal areas led by the German International Cooperation Agency (GIZ) or the Inter-American Development Bank (IDB). In this way, governments, multilateral organizations, and certain international cooperation bodies become facilitators and guarantors for the penetration of capital into rural areas to transform them into tourism regions (Palafox et al., 2016).

In this context, a clear example of the transformation driven by tourism is the province of Guanacaste in northern Costa Rica, on the border with Nicaragua. Until the early 1990s, the farming sector was dominated by large ranches dedicated to livestock rearing and traditional single-crop farming of sugarcane or rice, for example (Cabrera, 2007; Edelman, 1992; Gutiérrez, 1991; Rodríguez, 1989). The local peasant farmers alternated between day labor on these ranches and working on their own small plots; there was also a large fishing industry. Today, the coastal areas are dominated by tourism/ real-estate investment (Janoschka, 2011; Noorloos, 2012), while inland there has been an expansion of intensive farming of crops for export, such as melons or watermelons, in addition to traditional activities.

\section{THE IMPLICATIONS of Building a Tourist Area}

The multiple scales involved in this territorial reorganization need to be differentiated, as the rural areas where these transformations are taking place are not all occupied to the same extent and at the same time by this new tourism dynamic. In this vein, earlier economic dynamics coexist to a greater or lesser extent alongside the processes of construc- 
tion and implementation of the new tourist area within rural zones. However, as the process moves forward, and depending on a number of factors, rural communities are subject to a violent dynamic that involves either progressive "depeasantization" (Gascón and Ojeda, 2014) and subordinate integration into new activities, or migration and integration into other urban and peri-urban spaces.

Three broad dynamics can be identified in this process that in turn generate conflicts which, depending on their intensity and the historical and institutional framework within which they occur, end up specifically shaping the "touristified" societies and territories.

\section{Dispossession processes of essential natural resources and dismantling of territoriality associated with existing farming and fishing economies}

For rural communities, the construction of tourist areas involves the plunder of natural resources such as land and forests, particularly mangrove swamps, in order to build the new infrastructure required by tourism. The plundering of land can be undertaken in different ways, from market pressures through speculation in land values to regulatory changes in how land use is governed, and even through the use of physical violence. Speculative practices with regard to land prices have favored land ownership being transferred from local actors to investors, as different research carried out in Nicaragua (Bonilla and Mortd, 2011; Guobjört, 2014; Hunt, 2011) and Panama (Rudolf, 2014) has shown. In this sense, for example, land prices in the coastal town of Tola in Nicaragua went from \$300 a manzana (0.7 hectares/1.7 acres) in the mid-1990s, to $\$ 280,000$ shortly before the start of the international economic crisis in 2007 (Bonilla and Mortd, 2011). These processes represent similar dynamics to those described for other sectors also linked to "land grabbing” (Borras et al., 2012; Merlet and Jamart, 2009).

Similarly, the construction of the material support necessary to develop tourist activities involves destroying, or at the very least impacting upon, important ecosystems that extend far beyond the specific areas of land where peasant families from the area would be able to live and work. Examples of this include: the destruction of mangrove forests and wetlands; water pollution; the accumulation of solid waste; earthmoving and the destruction of hillsides to create terraces; and the loss and/or fragmentation of forests.

One ecosystem that is most under threat from expanding tourism is the mangrove forests that can be found in many tropical and subtropical coastal areas in Latin America, mainly in Mexico, Brazil and most Central American and Caribbean nations. Major areas of mangrove forests have been built over, used to facilitate transport between the constructed areas and the sea, or have even been replaced by other natural environments that better align with standardized aesthetic landscape models in tourist areas. In this way, the growth in tourism in the large area between Mexico, the Caribbean and Central America, for example, seen in successive waves over the last 40 years, has gone hand in hand with a decrease and degradation in so-called "saltwater forests." First, their destruction brings with it major ecological damage and consequences as they are a privileged setting for the reproduction and protection of many species (especially fish, snails, mollusks and crabs, but also birds) and house a wide variety of biodiversity. Furthermore, they are more vulnerable to the effects of natural phenomena such as storms, tsunamis, and ever stronger and more frequent hurricanes owing to growing climate change, given that the forests provide natural protection or form absorption barriers (Alongi, 2002; Hall, 2001; Rönnbäck, 1999).

Moreover, the loss of mangroves also erodes the livelihoods of coastal populations, leaving them poorer and reducing the likelihood of them being able to stay on their lands. The forests are a source of food for many coastal communities whether through collecting snails, crabs, seafood, etc., or through smallscale fishing. They are also a source of raw materials for building, among other things, their means of transport and construction, with an entire material culture and identity having been forged around the mangrove swamps. Their loss thus becomes a factor in "depeasantization" through the destruction of the material basis upon which many families along the coast settle and reproduce (Alvarado and Taylor, 2014; Mellado, 2012; Navarro, 2013).

Where tourism developments begin construction or come into operation, water also becomes subject to competing demands, given the requirements of 
tourist/residential real-estate complexes in contrast to the domestic use of the local population or use for crop irrigation. Water use in tourism is linked to personal use by guests (washing, spas, swimming pools), maintaining gardens and golf courses, etc., as well as to the "indirect" needs that arise from the way the tourism industry operates. Various research in many different contexts provides proof that water use by tourism is higher than that for domestic activities among the local population (Hof and Blàzquez, 2015; Hof and Schmitt, 2011; Gössling and Paul, 2015). Water shortages in many of these areas have entailed investors seeking to transfer water to other areas at the expense of the needs of the local communities who also use it. Competition surrounding water use is becoming a critical issue. The province of Guanacaste in Costa Rica has a dry tropical climate with very limited rainfall during part of the year and is home to many conflicts linked to competition for water among rural communities and tourism/residential property investors, such as those in the communities of Sardinal, Sámara and Nimboyores (Kuzdas, 2011); indeed, some sewerage work has put the very survival of these communities at risk (Fernández, 2009; Navas, 2015; Navas and Cuvi, 2015).

In this respect, it is also significant that Monsignor Vitorino Guanacaste, bishop of the diocese of Tilarán-Liberia in Guanacaste, Costa Rica, appealed for a moratorium on new tourism/residential property projects in 2009 in the face of a risk of collapse linked largely to the lack of water (Girardi, 2009: 16). Water conflicts have also had a major impact in terms of gender, as the division of laborreinforced by the tourism industry-has placed water within the sphere of social reproduction and, therefore, problems of scarcity or contamination have directly and primarily impacted women (Cole and Ferguson, 2015). In turn, women's responsibility for water, designated by these gender roles, has meant they have taken on a greater public profile in the fight against land-grabbing processes generated by the tourism industry. This was clearly seen in the conflict in Lorena, Guanacaste, between the rural community and the Nimboyores aqueduct project proposed by the Meliá Conchal tourism/residential property complex (Cole et al., 2016), or in the case of the aqueduct project in the community of Sardinal, both in the initial phase of the conflict

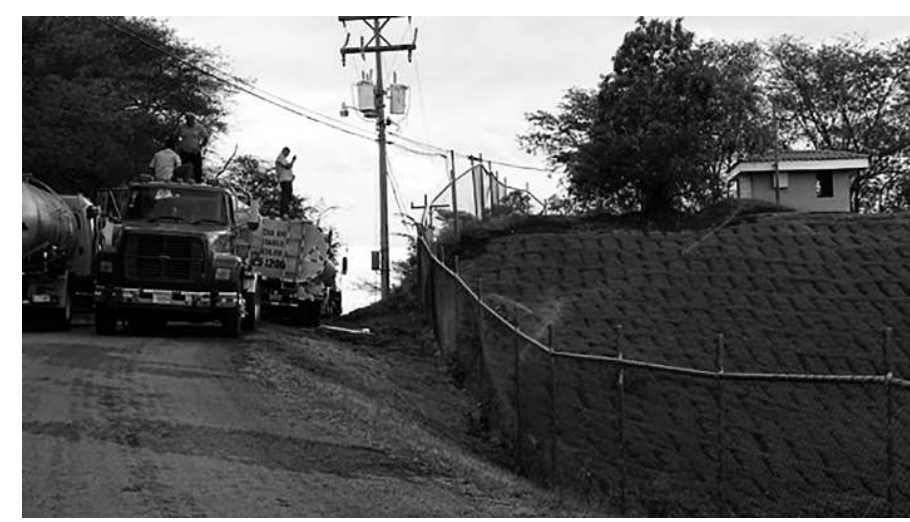

Figure 2 : State company lorries in Costa Rica supplying drinking water to a hotel in Guanacaste, Costa Rica (Source: photograph by Ernest Cañada, January 2017)

Camiones del Estado de Costa Rica abasteciendo un hotel de Guanacaste con agua potable hôtel de Guanacaste

Camions d'État au Costa Rica fournissant de l'eau potable à un

between 2008 and 2010 (Navas and Cubí, 2015) and as the basis for restarting the project in 2016 (Navarro, 2016; Arce and Navarro, 2017).

The impact of tourism on water for communities also includes contamination, especially from channeling sewage (Fernández, 2009). One of the best-known cases of this type of problem was the conflict at the Hotel Occidental Allegre Papagayo in Guanacaste, Costa Rica, which was closed by the Ministry of Health in February 2008 for environmental pollution. The hotel failed to install sufficient treatment plants for sewage and gray water when it was extended, meaning the wastewater was transported by lorry daily to a drain; however, due to the poor condition of the roads, some of this water spilled from the trucks and caused environmental pollution in several locations. As a result of protests from the affected communities and the environmental group Confraternidad Guanacasteca, the case gained media attention and led to the intervention of government authorities who temporarily shut down the hotel until it built the required water-treatment plants (Caribbean News Digital, February 12, 2008).

In turn, the way in which this new tourism/residential property business is implemented breaks down the preexisting territoriality among rural communities, promoting the displacement of homes and impeding access to certain thoroughfares and the coast (Bastos, 2013). For example, one of the main interventions in the Fomilenio II project in 
El Salvador, co-financed by the United States and El Salvador governments, will be to improve road links along the entire Pacific coastline to promote large-scale investment in tourism development; many communities see this as representing a displacement threat (Martínez, 2013). Similarly, many Garifuna communities along the Caribbean coast of Honduras, such as Barra Vieja in Tela or along the Bay of Trujillo, are being violently displaced from their legally recognized ancestral lands, or are facing this threat, to give way to tourism/residential property developments, thus making access to their livelihoods on the beaches more difficult (Trucchi, 2017; Lopera, 2016). Coastal communities in Costa Rica have suffered intense pressure from the town and country planning processes promoted by the government that have favored their movement away from the coastline to benefit tourism/residential property investments. The way in which town and country planning has been enforced in recent years in coastal areas of Costa Rica-through regulatory plans initially financed by tourism investors and then, when this was declared unconstitutional, by international development agencies - is an example of how the state acts on behalf of big business to the detriment of coastal populations. With their progressive separation from the coast and relocation to territories that are further away, communities traditionally linked to mangrove forests and fishing activities have seen how access to their livelihoods has been limited. In turn, transit routes and spots

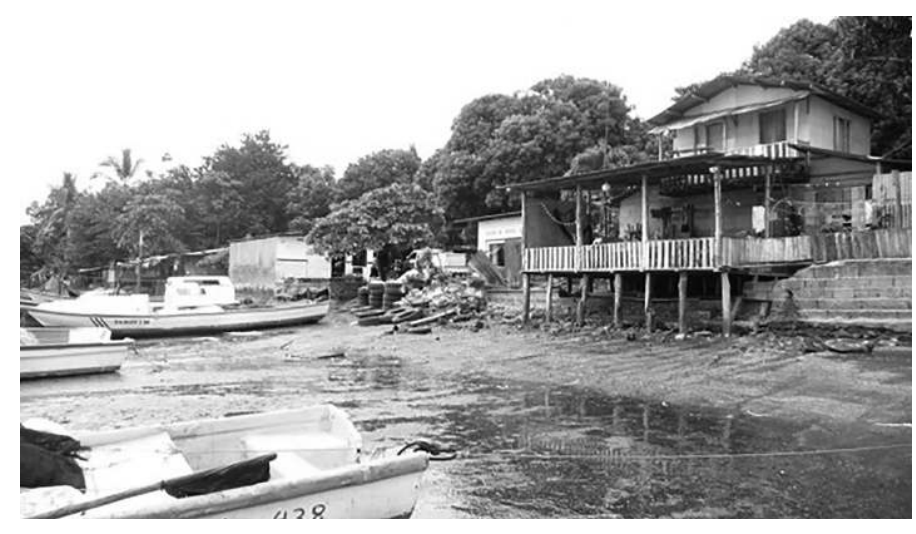

Figure 3. Costa de Pájaros, Guanacaste, Costa Rica. An example of a fishing community landscape with no tourism presence Source: photograph by Ernest Cañada, May 2009.

Littoral de Pájaros, Guanacaste, Costa Rica. Un exemple de paysage de communauté de pêcheurs sans présence touristique.

Litoral de Pájaros, Guanacaste, Costa Rica. Un ejemplo de paisaje de una comunidad de pescadores sin presencia del turismo that were open before are now subject to transit restrictions and all kinds of obstacles. In the end, these processes lead to more fragmented, exclusionary and privatized territories.

The growth in tourism/residential property investment that has taken place since the start of the 2000s, with a particular intensity in areas such as Guanacaste in Costa Rica, Rivas in Nicaragua and the Caribbean coast of Honduras, and driven by state policies to attract investment, has had a major impact on social groups that used to live in those regions and on the natural environment- deemed one of the losers in this transformation story (Janoschka, 2011). A major contradiction, and, in some instances, tension, between neoliberal economic policies and environmental policies has occurred in those countries. Furthermore, the conflicts between and among community organizations and social movements have tended to be resolved to the benefit of foreign investors; as María Paula Barrantes has shown, Costa Rica-the country that had done the most to support environmental conservation policies in the region (Barrantes, 2013) —went as far, in 2010, as to declare residential tourism to be in the national interest (Arce, 2010).

\section{Migratory dynamics caused by the expulsion of the rural population and by attracting new inhabitants, both workers and new residents}

New tourist areas lead to population movements in many senses. On the one hand, they expel peasants and fisherfolk as a result of dispossession processes. In turn, they attract workers for construction, as well as for tourist and ancillary services, who often come from other impoverished rural communities that have been impacted by neoliberal policies regarding agriculture and the peasant economy, and who are willing to migrate and supply labor for the job market of the global economy. Pressure from tourism/residential property activities and intensive agriculture (based on cheap migrant labor) means that many local people from a peasant background seek out work in other sectors, as demonstrated by the economically active population from Guanacaste province. According to census data, the number of people working in agriculture, stockbreeding and fishing declined from $26 \%$ to $17 \%$ between 2000 
and 2011, while those working in tourism increased from $20 \%$ to $22 \%$. On the other, land-value speculation puts a stop to many of the aforementioned activities, especially stockbreeding, and in many instances all activity ceases in expectation of better business opportunities.

In many Latin American destinations, foreign migrant labor has been systematically used-people who move without prior contracts and who are often illegal immigrants - to build hotels, homes and different kinds of infrastructure for tourism. This is true, for example, in the case of Nicaraguans in Guanacaste, Central Americans and Mexicans from the poorest states in Quintana Roo (Mexico), and Haitians in Punta Cana and Bávaro (Dominican Republic) (Cañada, 2013). They often live in provisional, self-built dwellings in these new regions, in overcrowded and unsanitary conditions (Acuña, 2011; Girardi, 2009; Vargas, 2013).

The region also attracts lots of migrants from Nicaragua to work in poorly paid jobs, as agricultural and construction day laborers, that are not generally taken up by the local population (Morales, 2012; Morales et al., 2011; Navarro, 2014). A study coordinated by Guillermo Acuña for different international and Costa Rican institutions demonstrated the precarious working conditions of construction laborers in Guanacaste, mostly Nicaraguan migrants who were working on the infrastructure required for tourism development. These conditions included a lack of social-security cover, scant health-and-safety measures and information on how to implement them, and long subcontracting chains that watered down company liabilities (Acuña, 2011).

Despite the low visibility of these types of situations, some tragic events have raised public awareness of the reality on the ground. This was true for the death of a construction worker on November 13, 2008, in Guanacaste due to the unsanitary living conditions he endured. Rafael Antonio Pérez Sánchez, a 26-year-old Nicaraguan and father of four, was working on the construction of the Hotel Riu Matapalo. He lived in an informal camp with 900 others. Due to a sewage leak into the water sources they drank from, over 200 workers fell ill and he died "after four days with stomach pains, vomiting and dehydration, without being able to eat, and dying in terrible loneliness" (Girardi, 2009: 15). In anger, the dead man's colleagues set fire to a bus from the transport company that took them to the construction site to denounce the situation in which they lived, attracting media attention and ultimately the attention of the public authorities, who temporarily shut down the work site (La Nación, November 18, 2008).

"Tourist spaces also attract a new population with higher spending power who work as middle and senior management at residential tourism facilities, as well as the users of these services themselves, whether short-term (tourists) or medium- and longterm (residents). These population changes represent new underlying social, cultural and political dynamics and processes" (Gascón, 2015; Janoschka and Sequeira, 2014; Noorloos, 2012). "The spatial and social dynamic becomes polarized between those areas dedicated to tourism production and those that ensure its reproduction" (Frausto et al., 2015).

The characteristics of the tourism model mean this new sector is also unable to fully absorb employment, which decreases in other activities. A significant proportion of residents of coastal communities live in conditions of deep poverty and marginality. Drug trafficking has also started to appear in the area, involving some inhabitants in the logistics of transporting drugs. In turn, certain migratory dynamics are also linked to the arrival of those working in illegal activities such as prostitution and drug dealing, as has been documented in Jacó in Costa Rica, for example (Caldarini, 2015).

\section{The integration of new labor dynamics generated by tourism that mostly have a subordinate character, whereby the local population hold the lowest posi- tions in the new employment structure}

Jobs created by tourism for communities (both those from the local area and those who migrate there) are generally precarious and at the bottom of the job scale both in construction and in customer service for visitors (cleaners, housekeeping, receptionists, kitchen staff, gardeners, security and vigilance, and entertainment).

Employees are often subject to exploitation: low salaries, irregular payments, subcontracts, police harassment, insecurity and occupational hazards. In turn, weak protection structures are put in place by 
employment ministries and unions, and workers systematically suffer harassment from bosses, making it difficult for them to create union organizations in tourist areas (Cañada, 2013; Iglesias, 2008). Acuña's report (Acuña, 2011) mentions the lack of union membership among these workers, which coincides with the fact that no hotel financed by Spanish capital in Costa Rica had a union branch at the time, according to a report released by Rel-UITA (Iglesias, 2008). In some areas, the presence of church-run social organizations is practically the only support these workers get.

This type of economic dynamic also attracts some people who are attempting to "get by" in the informal economy, offering products and services directly to tourists (including food and drink, souvenirs, handicrafts, and massages). However, their access to tourists is not always simple due to the restriction and privatization dynamics of exclusionary tourism development that has been labeled as a "sun(and(sea bunker" (Blàzquez et al., 2011). An example of this was clearly seen at the demonstration outside the Hotel Riu on March 1, 2010, by residents in Playa Matapalo, Guanacaste, who were protesting against the company impeding open access to the beach in front of the hotel, meaning street vendors were unable to sell to tourists. The demonstration was called by the Confraternidad Guanacasteca, the Federación Conservacionista (FECON) and the Federación de Estudiantes de la Universidad Centroamericana (Navarro, 2013).

An ethnographic study undertaken in the Nicaraguan municipality of San Juan del Sur demonstrated that the harshest - and even negative-attitudes towards the tourism industry came from employees at an ecotourism hotel, in contrast to the residents at the same establishment or those at a tree plantation with which the business had a relationship (Hunt and Stronza, 2014). The lack of opportunities to establish a more equitable relationship with the type of business where they earned a living was put forward as the most plausible explanation for this growing disaffection.

\section{Conclusions}

Far from concurring with more apologetic readings of tourism development as a synonym of modernization and well-being, the expansion of this activity into new areas under a logic of capitalist accumulation represents the adaptation of these areas to the needs of capital reproduction. This social transformation process is of a structurally violent nature (Büscher and Fletcher, 2016; Devine and Ojeda, 2017), based on the plunder of peasant populations and workers in construction, and in the new activities associated with the provision of services. It represents violence through the dispossession of natural resources and the dismantling of preexisting territory, with the subsequent "depeasantization" of large swaths of the population; violence through the displacement of large numbers of people who are forced to leave their lands; and finally, violence associated with labor integration under subordinate conditions and with no controls over the means of production or technical knowledge under which the new cycle of accumulation is developed. Despite the positive image created by the large lobbies representing the industry, its behavior can be linked to that of other extractive industries, such as mining or agribusiness, and, similarly, it ultimately opposes, through violent repression, communities' attempts to respond to it (Loperena, 2016).

Based on this interpretation framework of the implications of tourism development at regional level, what is required is a regional research agenda that connects the many insufficiently analyzed and understood elements. In this sense, the priorities to identify and analyze would be: (1) the different public and international cooperation policies and initiatives that have favored tourism development; (2) the infrastructures that have facilitated this process; (3) the new urbanization structures that have been created around tourism development, especially in coastal areas; (4) the different forms of capital involved, where they have come from, and how they have been mobilized to make this development possible; (5) the different processes of dispossession linked to the implementation of new spaces of accumulation based on tourism; (6) population movements, both displacement and arrivals, and the new urbanization of these spaces with a particular focus on the reproduction of spaces of tourism; and (7) the characteristics of employment created by tourism. Detailed research into each of these processes would enable us to make progress in obtaining a greater understanding of the implica- 
tions of tourism development within a framework of political ecology and economy.

\section{Aknowledgements}

The present article was written within the framework of the following projects: "CSO2015\&64468-P", managed by GIST-UIB and funded by the Ministry for the Economy and Competitiveness of the Government of Spain [Convocatoria 2015, Modalidad 1: Proyectos de I+D del Programa Estatal de Fomento de la Investigación Científica y Técnica de Excelencia, Subprograma Estatal de Generación del Conocimiento]; and "The Sustainable Development Goals and Tourism: Development Education Strategy" (Els Objectius de Desenvolupament Sostenible i el turisme: estratègia d'educació per al desenvolupament), managed by Alba Sud and funded by the Agència Catalana de Cooperació al Desenvolupament (ACCD) [Convocatòria 2017, línia 2: Projectes d’Educació per al Desenvolupament].

I would like to express my gratitude for the suggestions made and review of this text undertaken by Ivan Murray and Macià Blàzquez (University of the Balearic Islands, Spain), Jordi Gascón (University of Lleida, Spain), José Mansilla and Claudio Milano (Ostelea School of Tourism \& Hospitality, University of Lleida, Spain), Clément Marie dit Chirot (University of Angers) and Mario Sánchez (University of Central America, Nicaragua).

\section{References}

ACuña G., 2011 . Flujos migratorios laborales intrarregionales: situación actual, retos y oportunidades en Centroamérica y República Dominicana. Informe de Costa Rica, San José, OIM, OIT, MTSS, CECC SICA, Red de Observatorio del Mercado Laboral, 16 p.

Aguilar A., Palafox A., Anaya J.S., 2015. El turismo y la transformación del paisaje natural, Noésis. Revista de Ciencias Sociales y Humanidades, $n^{\circ} 24$, p. 19-30.

Alongi D.M., 2002. Present state and future of the world's mangrove forests, Environmental Conservation, no 29, vol. 3 , p. 331-349.

Alvarado N., Taylor M., 2014. ¿Del mar quién es dueño? Artisanal Fisheries, Tourism Development and the Struggles over Access to Marine Resources in Gigante, Nicaragua, Journal of Latin American Geography, n 13, vol. 3, p. 37-62.
Arce S., 2010. País fortalece servicios para atraer pensionados foráneos. Actividad es declarada de interés nacional. La Nación, February 19, 2010.

Arce M., Navarro S., 2017. A 10 años de lucha, Sardinal de nuevo en las calles por su agua. Alba Sud, February 23, 2017.

Arias R., Muñoz J.J., 2007. La reforma económica y su impacto social en Costa Rica durante el período de ajuste estructural: apuntes críticos para el análisis, Economía y Sociedad, no 31-32, p. 5-34.

Barrantes M.P., 2013. "Costa Rica, sin ingredientes artificiales": El rol del Estado en la expansión del turismo residencial en las zonas costeras, Anuario de Estudios Centroamericanos, 39, p. 233-261.

Bastos S., 2013. Territorial dispossession and indigenous rearticulation in the Chapala Lakeshore, in JanoschKa, M., HaAs H. (eds.), Contested Spatialities, Lifestyle Migration and Residential Tourism, Abingdon, Routledge, p. 47-59.

Blàzquez M., 2013. La difusión de las periferias de placer, in Cañada E. (ed.), Turismo en Centromérica. Un diagnóstico para el debate, Managua, Editorial Enlace, p. 39-41.

Blàzquez M., Cañada E., Murray I., 2011. Búnker playa-sol. Conflictos derivados de la construcción de enclaves de capital transnacional turístico español en El Caribe y Centroamérica, Scripta Nova: Revista Electrónica de Geografía y Ciencias Sociales, ${ }^{\circ} \mathrm{XV}$, vol. 368, (en línea).

Bonilla A., Mortd M., 2011 . Turismo en el municipio de Tola (Nicaragua): exclusión y resistencia local, Alba Sud-Opiniones en Desarrollo, $\mathrm{n}^{\circ} 11,28 \mathrm{p}$.

Borras S.M., Franco J.C., Gómez S., Kay C., Spoor M., 2012. Land grabbing in Latin America and the Caribbean, The Journal of Peasant Studies, no 39, vol. 3-4, p. 845-872.

Britton S., 1982. The Political Economy of Tourism in the Third World, Annals of Tourism Research, n 9, p. 331-358.

Büscher B., Fletcher R., 2016. Destructive creation: capital accumulation and the structural violence of tourism, Journal of Sustainable Tourism, vol. 25, n 5, p. 651-667

Bustos A., 2010. La apertura comercial en Costa Rica, Ciencias Económicas, $\mathrm{n}^{\circ} 28$, vol. 2, p. 215-248.

Cabrera R., 2007. Tierra y ganadería en Guanacaste, Editorial Tecnológica de Costa Rica, Cartago, 860 p.

Calderini T., 2015. Tourisme et migrations sur la côte pacifique du Costa Rica. Les dynamiques spatiales de la ville de Jacó, Université de Paris-Diderot - UFR GHSS, Mémoire de Master de Géographie et Sciences des Territoires, 105 p.

Cañada E., 2013. Turismo en Centroamérica. Un diagnóstico para el debate, Enlace, Managua, $164 \mathrm{p}$.

Cañada E., Blázquez M. (ed.), 2011. Turismo placebo: Nueva colonización turística: Del Mediterráneo a Mesoamérica y El Caribe: Lógicas espaciales del capital turístico, Enlace, Managua, $410 \mathrm{p}$.

Cañada E., Gascón J., 2016. Urbanizar el paisaje: turismo residencial, descampesinización, gentrificación rural. Una introducción, in GaScón J., CAÑada E., Turismo residencial y gentrificación rural, El Sauzal, Tenerife, PASOS, Revista de Turismo y Patrimonio Cultural, p. 5-36. 
Carvajal G., 1993. Costa Rica en la época de los programas de ajuste estructural, 1985-1992, Reflexiones. Revista Facultad Ciencias Sociales Universidad de Costa Rica, $\mathrm{n}^{\circ}$ 7, vol. 1, (en línea).

Castree N., 2008. Neoliberalising nature: The logics of deregulation and reregulation. Environment and Planning $A, \mathrm{n}^{\circ}$ 40, vol. 1, p. 131-152.

CEPAL, 2001. Inversión extranjera y desarrollo en Centroamérica: Nuevas tendencias, CEPAL, Santiago de Chile, LC/ MEX/L.509/E.

Cole S., Ferguson L., 2015. Towards a gendered political economy of water and tourism, Tourism Geographies, ${ }^{\circ} 17$, vol. 4, p. 511-528.

Cole S., Ferguson L., Leghari R., 2016. Women, Water and Tourism in Costa Rica, CAWN, briefing paper, july, 3 p.

Cordero A., 2006. Nuevos ejes de acumulación y naturaleza. El caso del turismo, Buenos Aires, CLACSO.

Cruz-Coria E., Zizumbo-Villarreal L., Cruz-Jiménez G., Quintilla-Montoya A.L., 2012. Las dinámicas de dominación capitalista en el espacio rural: la configuración de paisajes turísticos, Cuadernos de desarrollo rural, $\mathrm{n}^{\circ} 9$, vol. 69, p. 151-174.

Cuéllar N. (coord.), 2012. Inversiones y dinámicas territoriales. Implicaciones para la gobernanza y la construcción de alternativas, Fundación PRISMA, San Salvador, 69 p.

Devine J., 2017. Colonizing space and commodifying place: tourism's violent geographies geographies, Journal of Tourism Research, vol. 25, n 5, p. 634-650.

Devine J., Ojeda D., 2017. Violence and dispossession in tourism development: a critical geographical approach, Journal of Sustainable Tourism, vol. 25, n 5, p. 605-617.

Dieke P.U.C., 1995. Tourism and structural adjustment programmes in the African economy, Journal Tourism Economics, $\mathrm{n}^{\circ}$ 1, vol. 1, p. 71-93.

Duarte J.B., 2011. Tourism: A Challenge in the Face or Poverty, Americas, vol. 63, n 5, p. 28.

Edelman M., 1992. The logic of the latifundio. Large Estates of Northwestern Costa Rica Since the Late Nineteenth Century. Stanford University Press, Stanford, 496 p.

Fernández O., 2009. Papagayo, Sardinal y la gobernanza en Costa Rica: dos intervenciones del Estado y sus distintas consecuencias, Reflexiones, Revista Facultad Ciencias Sociales Universidad de Costa Rica, no 88, vol. 2, p. 9-16.

Fernández R., Ruiz R., 2011 . Políticas públicas, beneficios privados. Mecanismos, políticas y actuaciones públicas para la globalización del turismo, Foro de Turismo Responsable, Madrid, $229 \mathrm{p}$.

Fletcher R., 2011. Sustaining Tourism, Sustaining Capitalism? The Tourism Industry's Role in Global Capitalist Expansion, Tourism Geographies, vol. 13, n³ 3, p. 443-461.

Fletcher R., 2016. Tours caníbales puesto al día: la ecología política del turismo, Ecología Política, vol. 52, p. 26-34.

Frausto O., Vázquez A., Fraga J., 2015. Entre enclaves turísticos: pueblos de apoyo o asentamientos de trabajadores, in Fraga J., Khafash L., Córdoba J. (coord.). Turismo y ocio. Reflexiones sobre el Caribe mexicano, El Sauzal, Pasos, p. 183-211.
GASCón J., 2012. Introducción. Apuntes para un análisis crítico del turismo, in Buades J. Cañada E., Gascón J., El turismo en el inicio del milenio. Una lectura crítica a tres voces, Madrid, Foro de Turismo Responsable, p. 11-21.

Gascón J., 2015 (early view). Residential tourism and depeasantisation in the Ecuadorian Andes, The Journal of Peasant Studies (DOI: 10.1080/03066150.2015.1052964).

Gascón J., 2016. Turismo residencial y crisis de la agricultura campesina. Los casos de Vilcabamba y Cotacachi (Andes ecuatorianos), Pasos, Revista de turismo y patrimonio cultural, n ${ }^{\circ} 14$, vol. 2, p. 309-318.

Gascón J., OJeda D., 2014. Turistas y campesinado: El turismo como vector de cambio de las economías campesinas en la era de la globalización, Madrid/Tenerife, FTR/Pasos edita.

Girardi V., 2009. Carta Pastoral. Discípulos, tras las huellas de Cristo promoviendo la vida en el Norte de Costa Rica de 19 de junio de 2009, Liberia, Diócesis de Tilarán-Liberia.

Gómez I., 2008. Turismo y gestión territorial en Centroamérica: claros y oscuros en un proceso acelerado, San Salvador, Fundación PRISMA.

Gössling S., Peeters P., 2015. Assessing tourism's global environmental impact 1900-2050, Journal of Sustainable Tourism, $\mathrm{n}^{\circ} 23$, vol. 5 , p. 639-659.

Guobjört A., 2014. Land Tenure and Tourism Development in Nicaragua. A case study from Playa Gigante. Thesis submitted in partial fullfillmewnt of the requirements for the Degree of Master of Philosophy in Culture, Environment and Sustainability, University of Oslo, 119 p.

GutiérRez N., 1991. La estructura agraria costarricense en la década de los 70, Ciencias Sociales, no 51-52, p. 99-111.

Hall M., 2001. Trends in ocean and coastal tourism: the end of the last frontier?, Ocean $\&$ Coastal Management, $\mathrm{n}^{\circ} 44$, p. 601-618.

Harvey D., 2003. The New Imperialism, Oxford University Press, Oxford.

Harvey D., 2014. Seventeen Contradictions and the End of Capitalism. Oxford University Press, Oxford.

Hawkins D.E., Mann S., 2007. The World Bank's role in tourism development, Annals of Tourism Research, $\mathrm{n}^{\circ}$ 34, vol. 2, p. 348-363.

Hof A., Blàzquez M., 2015. Changing tourism patterns, capital accumulation, and urban water consumption in Mallorca, Spain: a sustainability fix?, Journal of Sustainable Tourism, $\mathrm{n}^{\mathrm{o}} 23$, vol. 5, p. 770-796.

Hof A., Sснмiтt T., 2011. Urban and tourist land use patterns and water consumption: Evidence from Mallorca, Balearic Islands, Land Use Policy, no 28, vol. 4, p. 792-804.

Hunt C., 2011 . Passport to Development? Local Perceptions of the Outcomes of Post-Socialist Tourism Policy and Growth in Nicaragua, Tourism Planning \& Development, $\mathrm{n}^{\circ}$ 8, vol. 3, p. 265-279.

Hunt C., Stronza A., 2014. Stage-based tourism models and resident attitudes towards tourism in an emerging destination in the developing world, Journal of Sustainable Tourism, vol. 22, no 2, p. 279-298.

Iglesias E., 2008. Las cadenas hoteleras españolas en América Latina y las libertades sindicales, Montevideo, Rel-UITA. 
JanoschKa M., 2011. "Imaginarios del turismo residencial en Costa Rica. Negociaciones de pertenencia y apropiación simbólica de espacios y lugares-una relación conflictiva”, in Mazón T., Huete R., Mantecón A. (ed.), Construir una nueva vida. Los espacios del turismo y la migración residencial. Santander, Milrazones, p. 81-102.

Janoschka M., Sequera J., 2014. Procesos de gentrificación y desplazamiento en América Latina - una perspectiva comparativista. En Michelini, J. Desafíos metropolitanos. Un diálogo entre Europa y América Latina, Madrid, Los Libros de la Catarata, p. 82-104.

Konadu-Agyemang K., 2001. Structural adjustment programmes and the international tourism trade in Ghana, 1983-99: some socio-spatial implications, Tourism Geographies, $\mathrm{n}^{\circ}$ 3, vol. 2, p. 187-206.

Kuzdas C., 2012. Unpacking water conflict in Guanacaste, Costa Rica, GWF Discussion Paper, n 1242, Global Water Forum, Canberra, 8 p.

Latimer H., 1985. Developing-island economies: tourism vs agricultura, Tourism Management, $\mathrm{n}^{\circ}$ 6, vol. 1, p. 32-42.

Loperena C., 2016. Honduras is open for business: extractivist tourism as sustainable development in the wake of disaster? Journal of Sustainable Tourism, vol. 25, $\mathrm{n}^{\circ}$ 5, p. 618-633.

Lundgren J., 1975. Tourist impact/island entrepreneurship in the Caribbean, in Momsen R.P. (ed.) Geographical Analysis for Development in Latin America and the Caribbean, Chapel Hill, CLAG, p. 12-19.

Luxemburg R., [1912] 2013. La acumulación del capital. Ediciones Internacionales Sedov.

Martínez C., 2013. El Salvador’s Dance Between Development and Displacement, NACLA Report on the Americas, vol. 48, p. $70-73$.

MelLado M. E., 2012. Implantar turismo: ¿Sembrar desarrollo? El caso del archipiélago de Las Perlas, Panamá, en Cairo, H. et al. (eds.), Actas del XV Encuentro de Latinoamericanistas Españoles. Congreso Internacional «América Latina: la autonomía de una región», Madrid, Trama Editorial/CEEIB, p. 887-897.

Merlet M., Jamart C., 2009. Commercial pressures on land worldwide. Issues an conceptual framework, International Land Coalition, Serie Knowlege for Change, $n^{\circ}$ 6, 18 p.

Morales A. (coord.), 2012, Migraciones y derechos laborales en Centroamérica: características de las personas migrantes y de los mercados de trabajo, San José, FLACSO.

Morales A., Kandel S., Ortiz X., Díaz O., Acuña G., 2011. Trabajadores migrantes y megaproyectos en América Central, San Salvador, Programa de las Naciones Unidas para el Desarrollo (PNUD)/Universidad Centroamericana «José Simeón Cañas» (UCA).

Morales L.C., 2010. Cambios en el estilo nacional de desarrollo y promoción del sector turístico en Costa Rica, Ciencias Económicas, vol. 28, nº 2, p. 295-309.

Morales L.C., 2011. Crisis económica, desarrollo turístico y trabajo: el caso de los trabajadores de la comunidad de los Pargos, Guanacaste, Revista de Ciencias Económicas, no 29, vol. 1, p. 385-399.

Murray I., 2012. Geografies del Capitalisme Balear. Poder, metabolisme social i petjada ecològica d'una superpotència turística, Tesis para optar por el grado de Doctor en Geografía, Universidad de las Islas Baleares, Departamento de Ciencias de la Tierra.

Navarro S., 2013. Turismo e inmigración en Playa Matapalo, Sardinal, Costa Rica. Resistencias comunitarias y laborales, Anuario de Estudios Centroamericanos, n 39, p. 263-387.

Navarro S., 2014, Geopolítica en una «periferia del placer». Colonialidad turística en Costa Rica, Revista Ciencias Sociales, $\mathrm{n}^{\circ} 145$, p. 45-60.

Navarro S., 2016. Guanacaste: quieren reactivar el acueducto de Sardinal y el pueblo protesta. Alba Sud, October 4, 2016.

Navas G., 2015. El agua fluye hacia el turista, Letras Verdes. Revista Latinoamericana de Estudios Socioambientales, $\mathrm{n}^{\circ} 18$, p. 27-47.

Navas G., Cuvi S., 2015. Análisis de un conflicto socioambiental por agua y turismo en Sardinal, Costa Rica, Revista Ciencias Sociales, 150, vol. IV, p. 109-124.

Noorloos F., 2012. Whose place in the sun? Residential tourism and its implications for equitable and sustainable development in Guanacaste, Costa Rica, Delft, Eburon.

Palafox A., Escalera A., Anaya J., 2016. Turismo, geopolítica y actores locales: la transformación económica de Cozumel como destino turístico en el Caribe, in Espinoza R., Chávez R., Andrade E. (coord.), Estudios turísticos en regiones de México, Guadalajara, Universidad de Guadalajara/ Centro Universitario de la Costa, p. 129-148.

Pascual J., 2003. Del mar es de todos al mar reservado: turistas, poblaciones de pescadores y reservas marinas en Canarias, Pasos, Revista de turismo y patrimonio cultural, $\mathrm{n}^{\circ} 1$, p. 65-78.

Programa Estado de la Nación en Desarrollo Humano Sostenible (Costa Rica), 2014. Vigésimo primer Informe Estado de la Nación en Desarrollo Humano Sostenible. PEN, San José, 440 p.

Rodríguez C., 1989. Concentración de la tierra y precarismo en Guanacaste, 1950-1970, Ciencias Sociales, nº 43, p. 73-80.

Rodríguez E., López I., 2011. Circuitos secundarios de acumulación y competitividad territorial, Viento Sur, no 116 , p. $51-57$.

Rosa H., 2008. Perfiles y trayectorias del cambio económico en Centroamérica, una mirada desde las fuentes generadoras de divisas, San Salvador, Fundación PRISMA.

Rosset P., 2009. La Guerra por la tierra y el territorio, en CIDECI-Unitierra (ed.), Primer Coloquio Internacional In Memoriam Andrés Aubry: planeta tierra: movimientos antisistémicos, San Cristobal de las Casas, CIDECI-Unitierra Ediciones, p. 159-175.

Rudolf G., 2014. Desarrollo, ¿para quién y hasta cuándo? Impactos del turismo residencial en zonas rurales de Panamá, Canto Rodado, no 9, p. 85-110.

Sмiтн N., 2015. Gentrificación urbana y desarrollo desigual, Barcelona, Icaria Editorial, edición a cargo de Luz María García y Fernando Sabaté.

SITCA, 2013. Boletín de Estadísticas Turísticas de Centroamérica 2012, San Salvador, Secretaría de Integración Turística Centroamericana (SITCA). 
SITCA, 2016. Compendio de Estadísticas de Turismo de los Países Miembros del SICA 2016, Managua, Secretaría de Integración Turística Centroamericana (SITCA).

Trucchi G., 2017. Expolio de los territorios garífunas en Honduras: Impactos del extractivismo y la expansión turística, Barcelona, Alba Sud Editorial, colección Informes en Contraste, $n^{\circ} 3$.

Turner L., Ash J., 1991. La horda dorada. El turismo internacional y la periferia del placer, Madrid, Edymion.
VARGAS R., 2013. Una mirada socioeconómica a Guanacaste y su gente, Alba Sud (on line).

Vilchis A., Zizumbo L., Monterroso N. Arriaga E., Palafox A., 2016. Dinámicas capitalistas para la acumulación por despojo, Revista de Ciencias Sociales de Costa Rica, $\mathrm{n}^{\circ} 1$, p. 31-41.

Wallerstein I., 1979. The Capitalist World-Economy, Cambridge, Cambridge University Press. 